\title{
Visible-Light Photocatalytic Double C-H Functionalization of Indoles: A Synergistic Experimental and Computational Study
}

\author{
Uranbaatar Erdenebileg ${ }^{a}$ \\ Taye B. Demissie ${ }^{b}$ \\ Jørn H. Hansen*a \\ ${ }^{a}$ Department of Chemistry, UiT The Arctic University of Norway, \\ Hansine Hansens veg 54, 9037 Tromsø, Norway \\ jorn.h.hansen@uit.no \\ b Centre for Theoretical and Computational Chemistry (CTCC), \\ Department of Chemistry, UiT The Arctic University of Norway, \\ 9037 Tromsø, Norway
}
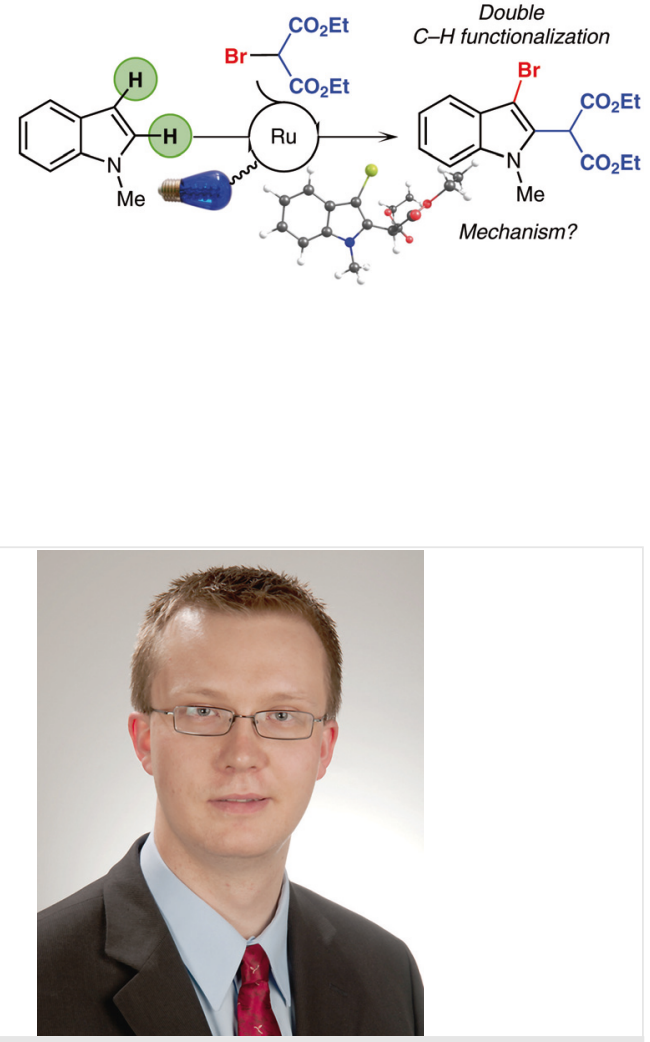

Jørn $\mathbf{H}$. Hansen received his PhD in organic chemistry from Emory University (Atlanta, GA) in 2010, followed by postdoctoral research at Princeton University, before joining UiT The Arctic University of Norway as an Associate Professor of Chemistry in 2012. His research interests range from development and applications of novel late-stage functionalization methods, chemical library design with bioactive and functional heterocycles, via computational mechanistic analysis to chemical education.

One of the first examples of selective intermolecular C$\mathrm{H}$ functionalization of heterocycles using VLPC came from Stephenson and co-workers, ${ }^{7}$ who showed that indoles and other heteroaromatics readily underwent $\mathrm{C}-\mathrm{H}$ malonation under photocatalytic conditions with diethyl bromomalonate and using 4-methoxy- $N, N$-diphenylaniline as base. For example, the C-2 malonation of $\mathrm{N}$-methylindole was achieved in $82 \%$ yield using $1 \mathrm{~mol} \%$ of ruthenium(II) trisbipyridine dichloride as the photocatalyst (Scheme 1 ). ${ }^{7}$ In this letter, we describe our recent discovery of a photocatalytic double $\mathrm{C}-\mathrm{H}$ functionalization process using indoles and diethyl bromomalonate. Our experimental efforts to understand the mechanism and scope, and to advance further development of this process, are detailed herein. Moreover, 


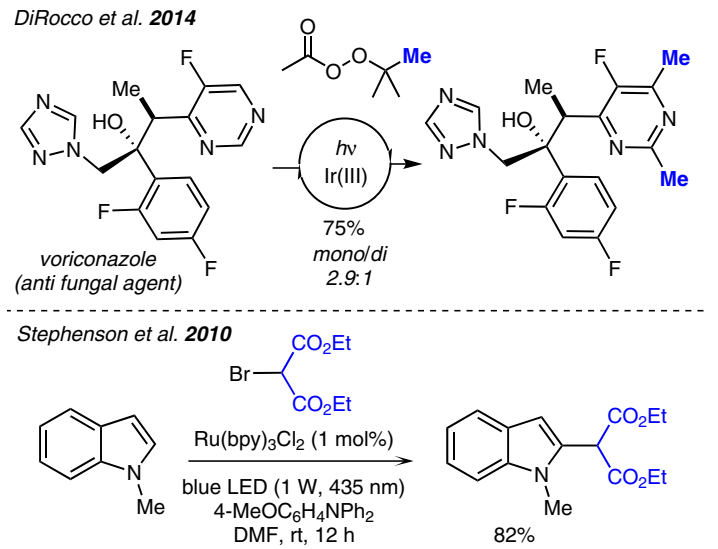

Scheme 1 Photocatalytic C-H functionalization of biologically interesting heterocycles

we have synergistically employed density functional theory calculations to assess a likely mechanism for the transformation.

Our work commenced with surveying reactions available in the literature. We attempted to reproduce the result by Stephenson and co-workers in which they achieved C-2 malonation of $\mathrm{N}$-methylindole (Scheme 1 ). ${ }^{7}$ We obtained a somewhat lower yield of $68 \%$ after 12 hours, but observed that the chemical yield appeared to decrease over time. After 48 hours reaction time, a new species was observed as the major product and identified as the 2,3-difunctionalized indole 2 , in which the $\mathrm{C}-2$ position contained the malonyl group, and the C-3 position was functionalized with bromine (Scheme 2). An ultra-high performance liquid chromatography (UPLC) study of the reaction progress revealed that product $\mathbf{1}$ is formed initially with a peaking concentration after ca. 10 hours (Figure 1). The difunctionalized indole 2 steadily grows in, reaching the maximum yield region after ca 24 hours. An 84\% isolated yield of 2 was

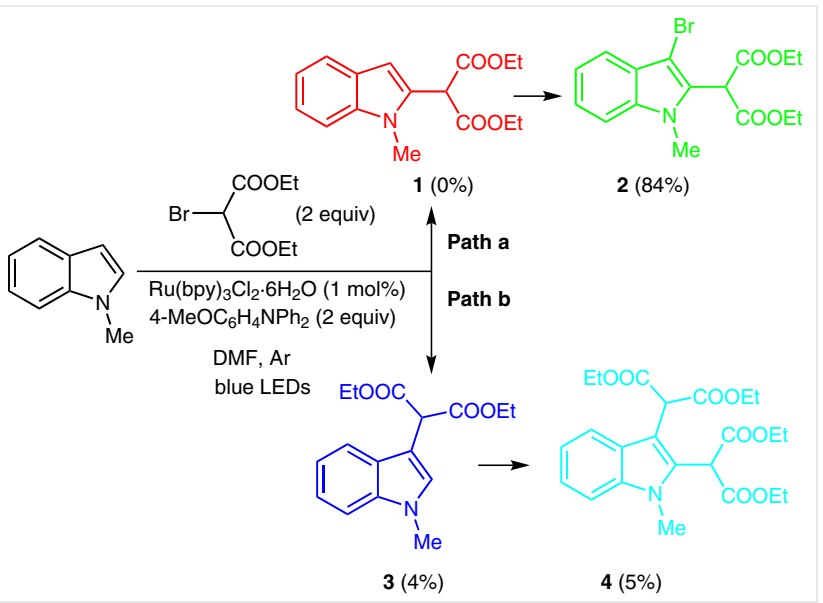

Scheme 2 Observed products in the model reaction observed after 48 hours reaction time, consistent with Figure 1. As shown in Scheme 2 and Figure 1, 1 and $\mathbf{2}$ are produced via the main reaction path a.

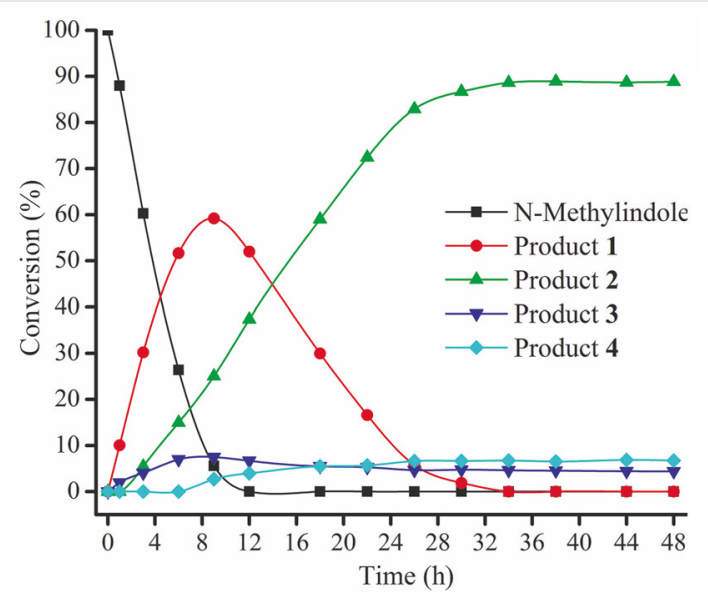

Figure 1 Product distribution as function of time for model reaction

On the other hand, reaction path $\mathrm{b}$ is operating, although slow compared to a, and yields $\mathrm{C} 3$-malonated product 3, which is a precursor for the formation of 4 . Figure 1 shows that $\mathbf{1}$ and $\mathbf{3}$ are formed in parallel, but that the formation of $\mathbf{1}$ is much faster. Moreover, the conversion study demonstrates that formation of $\mathbf{4}$ comes exclusively from $\mathbf{3}$. Finally, we have confirmed that $\mathbf{1}$ and $\mathbf{3}$ convert exclusively into 2 and 4, respectively, by control experiments in which pure $\mathbf{1}$ and $\mathbf{3}$ were separately subjected to the reaction conditions.

The influence of reaction conditions was surveyed to identify parameters of importance to control the product distribution in favor of compound $\mathbf{2}$ (Table 1 ). The reaction works with different common photocatalysts, although ruthenium(II) trisbipyridine hexahydrate afforded the largest amount of $\mathbf{2}$ after 48 hours reaction time. The reaction also worked in different solvents such as dichloromethane and acetonitrile, but the highest yield of $\mathbf{2}$ was observed in DMF. The base is a crucial factor, and only the triaryl base 4MeOC ${ }_{6} \mathrm{H}_{4} \mathrm{NPh}_{2}$ was effective at affording high yields of the desired product. The reactions are conducted using two equivalents of diethyl bromomalonate, which afforded a satisfactory reaction rate according to Figure 1 . However, when one equivalent of diethyl bromomalonate was employed, much slower conversion was observed, but product 2 was still formed as the major product after ca. 4-5 days. This result strongly suggests that both the bromine and the malonyl group in the final product come from the same equivalent of substrate. For a general procedure and representative analytical data, see reference $15 .{ }^{15}$

To investigate the generality of the newly discovered double $\mathrm{C}-\mathrm{H}$ functionalization process, various substrates were studied under the best reaction conditions from Table 1. Table 2 shows the isolated yields of $\mathrm{C}-2$ malonated het- 
Table 1 Influence of Reaction Variables ${ }^{\mathrm{a}}$

\begin{tabular}{|c|c|c|c|c|c|c|c|}
\hline \multirow[t]{2}{*}{ Entry } & \multirow[t]{2}{*}{ Catalyst } & \multirow[t]{2}{*}{ Base } & \multirow[t]{2}{*}{ Solvent } & \multicolumn{4}{|c|}{ Yield (\%) } \\
\hline & & & & 1 & 2 & 3 & 4 \\
\hline 1 & $\mathrm{Ru}(\mathrm{bpy})_{3}\left(\mathrm{PF}_{6}\right)_{2}$ & 4- $\mathrm{MeOC}_{6} \mathrm{H}_{4} \mathrm{NPh}_{2}$ & DMF & 4 & 81 & 7 & 8 \\
\hline 2 & $f a c-\operatorname{Ir}(\mathrm{ppy})_{3}$ & 4- $\mathrm{MeOC}_{6} \mathrm{H}_{4} \mathrm{NPh}_{2}$ & DMF & 6 & 78 & 6 & 10 \\
\hline 3 & $\operatorname{Ir}(\mathrm{ppy})_{2}(\mathrm{dtbbpy}) \mathrm{PF}_{6}$ & 4- $\mathrm{MeOC}_{6} \mathrm{H}_{4} \mathrm{NPh}_{2}$ & DMF & 5 & 77 & 7 & 11 \\
\hline 4 & $\mathrm{Ru}(\mathrm{bpy})_{3} \mathrm{Cl}_{2} \cdot 6 \mathrm{H}_{2} \mathrm{O}$ & 4- $\mathrm{MeOC}_{6} \mathrm{H}_{4} \mathrm{NPh}_{2}$ & $\mathrm{CH}_{2} \mathrm{Cl}_{2}$ & 2 & 84 & 6 & 8 \\
\hline $5^{c}$ & $\mathrm{Ru}(\mathrm{bpy}){ }_{3} \mathrm{Cl}_{2} \cdot 6 \mathrm{H}_{2} \mathrm{O}$ & $4-\mathrm{MeOC}_{6} \mathrm{H}_{4} \mathrm{NPh}_{2}$ & toluene & 19 & 7 & 1 & 3 \\
\hline 6 & $\mathrm{Ru}(\mathrm{bpy})_{3} \mathrm{Cl}_{2} \cdot 6 \mathrm{H}_{2} \mathrm{O}$ & 4- $\mathrm{MeOC}_{6} \mathrm{H}_{4} \mathrm{NPh}_{2}$ & $\mathrm{MeCN}$ & 11 & 74 & 4 & 11 \\
\hline 7 & $\mathrm{Ru}(\mathrm{bpy})_{3} \mathrm{Cl}_{2} \cdot 6 \mathrm{H}_{2} \mathrm{O}$ & 4- $\mathrm{MeOC}_{6} \mathrm{H}_{4} \mathrm{NPh}_{2}$ & DMF & 0 & $84^{d}$ & $4^{\mathrm{d}}$ & $5^{d}$ \\
\hline $8^{\text {c,e }}$ & $\mathrm{Ru}(\mathrm{bpy})_{3} \mathrm{Cl}_{2} \cdot 6 \mathrm{H}_{2} \mathrm{O}$ & 4- $\mathrm{MeOC}_{6} \mathrm{H}_{4} \mathrm{NPh}_{2}$ & DMF & 57 & 26 & 5 & 5 \\
\hline $9^{c}$ & $\mathrm{Ru}(\mathrm{bpy})_{3} \mathrm{Cl}_{2} \cdot 6 \mathrm{H}_{2} \mathrm{O}$ & $\mathrm{Et}_{3} \mathrm{~N}$ & DMF & 1 & 2 & 3 & 2 \\
\hline $10^{c}$ & $\mathrm{Ru}(\mathrm{bpy})_{3} \mathrm{Cl}_{2} \cdot 6 \mathrm{H}_{2} \mathrm{O}$ & DIPEA & DMF & 0 & 0 & 0 & 0 \\
\hline $11^{c}$ & $\mathrm{Ru}(\mathrm{bpy})_{3} \mathrm{Cl}_{2} \cdot 6 \mathrm{H}_{2} \mathrm{O}$ & pyridine & DMF & 0 & 0 & 0 & 0 \\
\hline $12^{c}$ & $\mathrm{Ru}(\mathrm{bpy})_{3} \mathrm{Cl}_{2} \cdot 6 \mathrm{H}_{2} \mathrm{O}$ & DBU & DMF & 0 & 0 & 1 & 3 \\
\hline
\end{tabular}

a Unless otherwise stated, the reaction conditions were: $\mathrm{N}$-methylindole $(0.5 \mathrm{mmol})$, diethyl bromomalonate $(1.0 \mathrm{mmol}, 2.0$ equiv), photocatalyst (0.005 mmol, $1.0 \mathrm{~mol} \%$ ), base (1.0 mmol, 2.0 equiv), and solvent ( $2 \mathrm{~mL}$ ), argon atmosphere, 1 W blue LED light (for ruthenium-based catalysts) or $1 \mathrm{~W}$ white LED strips (for iridium-based catalysts) at r.t., $48 \mathrm{~h}$.

b Unless otherwise stated, yields were calculated on the basis of UPLC analysis of the crude products.

c $\mathrm{N}$-Methylindole was not fully consumed after $48 \mathrm{~h}$.

d Isolated yields.

e With only 1 equiv of diethyl bromomalonate.

Table 2 Isolated Yields of Mono- and Disubstituted Derivatives from Indoles, Benzofuran and Benzothiophene after 48 Hours of Reaction $^{\mathrm{a}}$

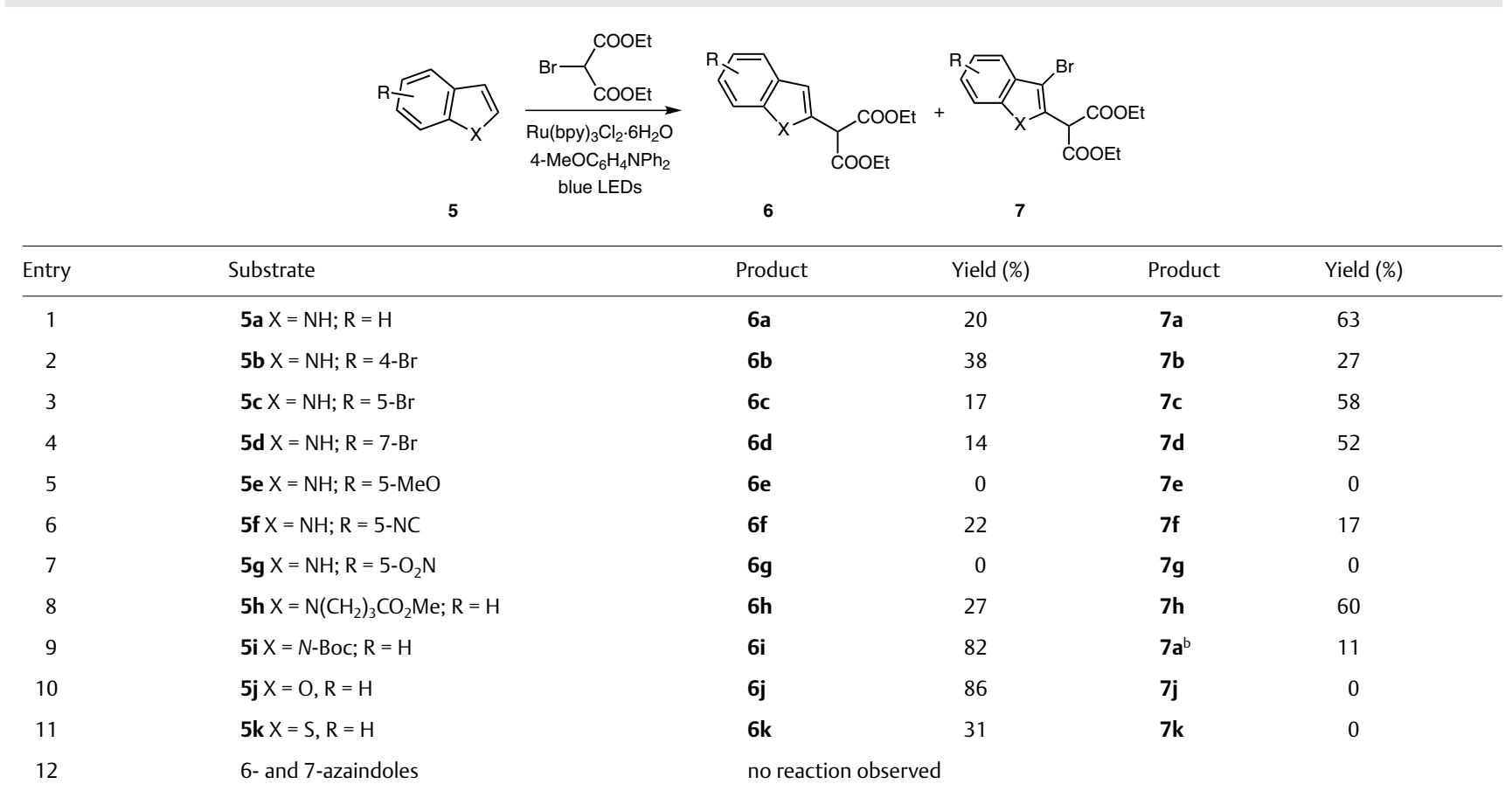

a Reaction conditions: heterocyclic substrate $(0.5 \mathrm{mmol})$, diethyl bromomalonate $(1.0 \mathrm{mmol}, 2.0$ equiv), tris(bipyridine)ruthenium(II) chloride hexahydrate $(0.005$ mmol, $1.0 \mathrm{~mol} \%)$, 4-methoxy- $\mathrm{N}, \mathrm{N}$-diphenylaniline ( $1.0 \mathrm{mmol}$, 2.0 equiv), and DMF ( $2 \mathrm{~mL})$, argon atmosphere, $1 \mathrm{~W}$ blue LED strips at r.t., $48 \mathrm{~h}$.

${ }^{\mathrm{b}}$ The Boc group was lost spontaneously during the reaction. 
erocycles $\mathbf{6 a}-\mathbf{k}$ and doubly functionalized products $\mathbf{7 a - k}$. For most substrates, full conversion to difunctionalized product was not observed after 48 hours reaction time.

The reaction rates appeared very sensitive to the substituents, and in several cases, byproducts were also formed from other pathways (Figure 2). As such, reaction time is a crucial and very substrate-specific parameter. Unsubstituted indole (5a) afforded $7 \mathbf{a}$ in $63 \%$ yield, with $20 \%$ of $\mathbf{6 a}$, indicating that slightly less electron-rich indoles require longer reaction times to be converted fully into the desired product. In a series of brominated indoles $\mathbf{5 b}-\mathbf{d}$, the difunctionalized product $\mathbf{7 b}$ was minor in the case of 4-bromoindole ( $27 \% \mathbf{7 b}$ vs. $38 \%$ of $\mathbf{6 b}$ ). Moreover, the formation of the C3 homodimer 8 (Figure 2) was observed in 18\% yield. In this case, the combined substituent effects of the 4-bromo and 2-malonyl groups must have rendered $\mathbf{6 b}$ amenable to photooxidation and subsequent homodimerization. In 5and 7-substituted indoles the yields of difunctionalized products were similar ( $58 \%$ and $52 \%$, respectively). 5-Bromo substitution appeared to more favor path $\mathrm{b}$, as the products 9 and 10 were isolated in overall 21\% yield (Figure 2). 7-Bromoindole (5d) also afforded a small amount of dimalonated product 11 in $18 \%$ yield, consistent with increased $\pi$-nucleophilicity at $\mathrm{C}-4$ in this system. The $\pi$-electron-donating methoxy substituent in the 5-position did not afford any desired product, but rather underwent dimalonation as well as homodimerizations to give a range of products 1214 (Figure 2). Too electron-rich $\pi$-systems lead to reaction pathways involving oxidation of the indole with subsequent side reactions over the bromination. 5-Cyanoindole (5f) gave approximately equimolar amounts of $\mathbf{6 f}(22 \%)$ and $7 \mathbf{f}$
(17\%), in addition to $C-3$ malonation ( $8 \%$ of 15 ); with the major product being $\mathrm{C}-3$ brominated product $\mathbf{1 6}$ formed in $32 \%$ yield. 5-Nitroindole (5g) did not yield any desired product, but afforded C-3 brominated indole 17 in $45 \%$ yield (Figure 2). These interesting observations suggest that the bromination can occur independently from the malonation and that electron-poor substrates favor the former over the latter process. The $\mathrm{N}$-substituted indole $\mathbf{5 h}$ afforded $60 \%$ of $\mathbf{7 h}$, suggesting that inductive electron-withdrawing effects of $\mathrm{N}$-substituents also cause reduced conversion rates to the desired difunctionalized product. In this case, the $\mathrm{C}-3$ malonated product $\mathbf{1 8}$, arising from path $\mathrm{b}$, was also observed in $6 \%$ yield. Boc-protected indole $\mathbf{5 i}$ afforded $11 \%$ of deprotected product 7a, consistent with the above-mentioned electronic effects. The deprotection occurs spontaneously under the reaction conditions. Attempts to extend the chemistry to benzofuran (5j), benzothiophene (5k) and azaindoles failed to produce any difunctionalization. In the cases of $\mathbf{5 j}$ and $\mathbf{5 k}$ the $\mathrm{C}-2$ monofunctionalized products were observed exclusively in $86 \%$ and $31 \%$ yields, respectively. No conversion was observed for the azaindoles.

We next attempted to extend the difunctionalization chemistry to more basic heterocycles such as pyrrole (19a), furan (19b), and thiophene (19c) (Table 3). In these cases, we did not observe any bromination, only mixtures of mono- $(\mathbf{2 0 a}-\mathbf{c})$ and dimalonated $(\mathbf{2 1 a}-\mathbf{c})$ products.

In order to understand our newly discovered double C$\mathrm{H}$ functionalization process, and to obtain mechanistic information to develop the chemistry further, we studied various mechanistic possibilities using contemporary DFT<smiles>CCOC(=O)c1[nH]c2cccc(Br)c2c1-c1c(C(C(=O)OCC)C(=O)OCC)[nH]c2cccc(Br)c12</smiles><smiles>CCOC(=O)C(C(=O)OCC)c1c[nH]c2ccc(Br)cc12</smiles><smiles>CCOC(=O)C(C(=O)OCC)c1[nH]c2ccc(Br)cc2c1C(C(=O)OCC)C(=O)OCC</smiles>

$10,12 \%$<smiles>CCOC(=O)C(C(=O)OCC)c1cc2c(C(OCC)OCC)ccc(Br)c2[nH]1</smiles>

$11,18 \%$<smiles>CCOC(=O)C(C(=O)OCC)C(C(=O)OCC)c1cc2c(OC)ccc(OC)c2[nH]1</smiles>

$12,45 \%$<smiles>CCOC(=O)C(C(=O)OCC)c1c[nH]c2ccc(C#N)cc12</smiles>

$15,8 \%$<smiles>CCOC(=O)C(C(=O)OCC)c1cc2c(-c3c(C(C(=O)OCC)C(COC)OCC)[nH]c4ccc(OC)cc34)c(OC)ccc2[nH]1</smiles>

$13,10 \%$<smiles>CCOC(=O)C(C(=O)OCC)C(C(=O)OCC)c1[nH]c2ccc(OC)c(C(C(=O)OCC)(C(=O)OCC)C(C)OCC)c2c1-c1c(OC)ccc2[nH]c(C(C(=O)OCC)C(C)OCC)cc12</smiles>

$14,28 \%$

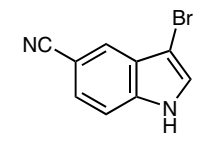

$16,32 \%$<smiles>O=[N+]([O-])c1ccc2[nH]cc(Br)c2c1</smiles>

$17,45 \%$<smiles>CCOC(=O)C(C(=O)OCC)c1cn(CCCC(C)=O)c2ccccc12</smiles>

$18,6 \%$

Figure 2 Characterized byproducts and their isolated yields 
techniques in conjunction with experimental control experiments. A major goal was to try to understand how the $\mathrm{C}-\mathrm{H}$ bromination occurs.

Table 3 Isolated Yields of Mono- and Dimalonated Derivatives from Pyrrole, Furan, and Thiophene ${ }^{a}$

\begin{tabular}{|c|c|c|c|c|c|}
\hline $\begin{array}{l}\left\langle X^{\prime}\right. \\
19\end{array}$ & $\begin{array}{l}\underset{\mathrm{Ru}(\mathrm{bpy})_{3} \mathrm{Cl}_{2} \cdot 6 \mathrm{H}_{2} \mathrm{O}}{\mathrm{COOEt}} \\
\text { 4- } \mathrm{MeOC}_{6} \mathrm{H}_{4} \mathrm{NPh}_{2} \\
\text { blue LEDs }\end{array}$ & $Y_{\text {COC }}^{c 0}$ & + & 2 & $T_{C 00}$ \\
\hline Entry & Substrate & Product & Yield (\%) & Product & Yield (\%) \\
\hline 1 & 19a, $X=N H$ & $20 a$ & 51 & $21 a$ & 33 \\
\hline 2 & $19 b, X=O$ & $20 b$ & 20 & $21 b$ & 72 \\
\hline 3 & $19 c, X=S$ & $20 c$ & 54 & $21 \mathrm{c}$ & 19 \\
\hline
\end{tabular}

${ }^{a}$ Reaction conditions: heterocyclic substrate $(0.5 \mathrm{mmol})$, diethyl bromomalonate $(1.0 \mathrm{mmol}, 2.0$ equiv), tris(bipyridine)ruthenium(II) chloride hexahydrate $(0.005 \mathrm{mmol}, 1.0 \mathrm{~mol} \%)$, 4-methoxy- $N, N$-diphenylaniline $(1.0$ mmol, 2.0 equiv), and DMF ( $2 \mathrm{~mL})$, argon atmosphere, $1 \mathrm{~W}$ blue LED strips at r.t., $48 \mathrm{~h}$.

We have recently disclosed two DFT studies of photocatalytic $\mathrm{C}-\mathrm{H}$ functionalization processes, in one of which the C-2 malonation of indoles was studied in detail (see the Supporting Information). ${ }^{16,17}$ Herein, we discuss our proposed mechanism for double $\mathrm{C}-\mathrm{H}$ functionalization of $\mathrm{N}$ methylindole (Scheme 3) with energies calculated at the B3LYP-D3BJ/6-311+G(d,p)/DMF(IEF-PCM) level of theory.

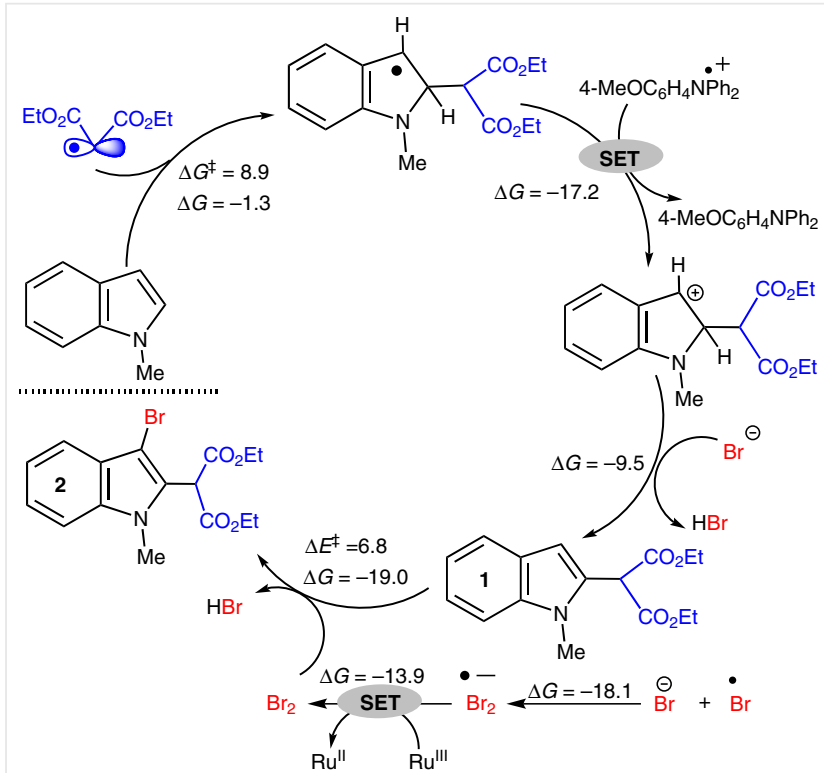

Scheme 3 Experimentally supported, proposed reaction mechanism for the photocatalytic double $\mathrm{C}-\mathrm{H}$ functionalization of 1-methylindole, calculated using B3LYP-D3BJ/6-311+G(d,p)/DMF(IEF-PCM)
The $\mathrm{C}-2$ addition is the kinetically favored pathway with an energy barrier of $8.9 \mathrm{kcal} / \mathrm{mol}$ in the addition step, compared to $10.2 \mathrm{kcal} / \mathrm{mol}$ barrier for $\mathrm{C}-3$ addition, consistent with the observed product distribution in Figure 1.

The computed and experimental product distributions are in good agreement in this case and provide the rationale for our choice of computational methodology (see the Supporting Information for comparison with alternative method). The addition step is followed by exergonic singleelectron transfer (SET, $-17.2 \mathrm{kcal} / \mathrm{mol}$ ) and subsequent elimination of bromide ion $(-9.5 \mathrm{kcal} / \mathrm{mol})$ to form 1 . For the bromination we assessed different possibilities (see the Supporting Information for details). Inspired by recent work by Meyer and co-workers, ${ }^{18}$ we hypothesized that the reaction could involve electrophilic bromination by small amounts of $\mathrm{Br}_{2}$, formed via photocatalytic oxidation of bromide ions that are generated throughout the reaction. Examples of mild bromination of C-2-substituted indoles in DMF exist in the literature, ${ }^{19}$ and this was also found to be feasible both computationally and by a control experiment. In the control experiment, 1 was treated with $\mathrm{Br}_{2}$ in $\mathrm{DMF}$ and was shown to convert fully into 2 . Finally, the $\mathrm{HBr}$ salt of the triaryl base was prepared independently and could be shown to effect the bromination of $\mathbf{1}$ under the photocatalytic reaction conditions. These observations strongly support our mechanistic proposal. The photocatalyst can oxidize bromide ions to radicals, ${ }^{20}$ which then react with bromide ions exergonically to form $\mathrm{Br}_{2}{ }^{-{ }^{-}}(-18.1 \mathrm{kcal} / \mathrm{mol})$, consistent with the Meyer study. ${ }^{18}$ The $\mathrm{Br}_{2}{ }^{-}$can then become oxidized by the ruthenium(III) photocatalyst to molecular bromine, which was also found to be exergonic by $-13.9 \mathrm{kcal} / \mathrm{mol}$. We were unable to obtain a proper transition state for the bromination of 1 with $\mathrm{Br}_{2}$, but a PES scan revealed an approximate potential energy barrier of 6.8 $\mathrm{kcal} / \mathrm{mol}$ for this reaction. Followed by $\mathrm{HBr}$ elimination, the transformation from 1 to 2 was exergonic by $-19 \mathrm{kcal} / \mathrm{mol}$.

In conclusion, we have demonstrated a novel photocatalytic double $\mathrm{C}-\mathrm{H}$ functionalization of $\mathrm{C}-2$ and $\mathrm{C}-3$ positions of indoles. Moreover, we have studied mechanistic details of the transformation by DFT and by careful examination of the reaction progress and byproduct formation. The results suggest that two independent photocatalytic processes occur to produce the observed difunctionalization and that the secondary reaction occurs through oxidation of bromide ions formed during the reaction progress. This can generate molecular bromine amenable to $\mathrm{C}-3$ bromination. The high sensitivity of the chemical yields toward electronic effects underscores the challenges involved in achieving selective $\mathrm{C}-\mathrm{H}$ multifunctionalizations. Studies to develop the photocatalytic $\mathrm{C}-\mathrm{H}$ bromination chemistry further are under way and will be disclosed in the near future. 


\section{Acknowledgment}

The authors would like to acknowledge generous funding for this project from the Department of Chemistry at UiT The Arctic University of Norway, and provision of computational resources from NOTUR (grant number NN4654K).

\section{Supporting Information}

Supporting information for this article is available online at http://dx.doi.org/10.1055/s-0036-1588719. Detailed experimental procedures, characterization and spectra, as well as computational details and xyz-coordinates, are included.

\section{References and Notes}

(1) Fagnoni, M.; Dondi, D.; Ravelli, D.; Albini, A. Chem. Rev. 2007, 107,2725

(2) Hoffmann, N. Chem. Rev. 2008, 108, 1052.

(3) Wang, C.; Qin, J.; Shen, X.; Riedel, R.; Harms, K.; Meggers, E. Angew. Chem. Int. Ed. 2016, 55, 685.

(4) Xuan, J.; Xiao, W.-J. Angew. Chem. Int. Ed. 2012, 51, 6828.

(5) Cernak, T.; Dykstra, K. D.; Tyagarajan, S.; Vachal, P.; Krska, S. W. Chem. Soc. Rev. 2016, 45, 546.

(6) DiRocco, D. A.; Dykstra, K.; Krska, S.; Vachal, P.; Conway, D. V.; Tudge, M. Angew. Chem. Int. Ed. 2014, 53, 4802.

(7) Furst, L.; Matsuura, B. S.; Narayanam, J. M. R.; Tucker, J. W.; Stephenson, C. R. J. Org. Lett. 2010, 12, 3104.

(8) Hari, D. P.; Schroll, P.; König, B. J. Am. Chem. Soc. 2012, 134, 2958.

(9) Nguyen, J. D.; D’Amato, E. M.; Narayanam, J. M. R.; Stephenson, C. R. J. Nat. Chem. 2012, 4, 854

(10) O'Hara, F.; Blackmond, D. G.; Baran, P. S. J. Am. Chem. Soc. 2013, 135,12122

(11) Yamaguchi, J.; Yamaguchi, A. D.; Itami, K. Angew. Chem. Int. Ed. 2012, 51, 8960 .

(12) Demissie, T. B.; Hansen, J. H. Dalton Trans. 2016, 45, 10878.

(13) Romero, N. A.; Margrey, K. A.; Tay, N. E.; Nicewicz, D. A. Science 2015, 349, 1326.
(14) Peña-López, M.; Rosas-Hernández, A.; Beller, M. Angew. Chem. Int. Ed. 2015, 54, 5006

(15) General Procedure

An oven-dried $10 \mathrm{~mL}$ round-bottom flask was equipped with a rubber septum and magnetic stirrer and was charged with the heteroaromatic substrate $(0.5 \mathrm{mmol}, 1.0$ equiv), tris(2,2'-bipyridyl)ruthenium(II) chloride hexahydrate $(5.0 \mu \mathrm{mol}, 3.70 \mathrm{mg}, 1.0$ mol\%), 4-methoxyphenyl- $\mathrm{N}, \mathrm{N}$-diphenylamine ( $1.0 \mathrm{mmol}, 0.274$ g, 2.0 equiv), diethyl bromomalonate $(1.0 \mathrm{mmol}, 0.239 \mathrm{~g}, 2.0$ equiv), and DMF $(2.0 \mathrm{~mL})$. The mixture was degassed by the freeze-pump-thaw method, and the reaction vessel was filled with argon. A $1 \mathrm{~W}$ blue light-emitting diode (LED) strip was placed around the reaction vessel at a distance of approximately $2-4 \mathrm{~cm}$. The reaction was stopped by removing the LED lamps, and the mixture was poured into a separatory funnel containing EtOAc $(10 \mathrm{~mL})$ and water $(10 \mathrm{~mL})$. The layers were separated, and the aqueous layer was extracted with EtOAc $(2 \times 10 \mathrm{~mL})$. The combined organic phases were washed with brine $(10 \mathrm{~mL})$, dried (anhydrous $\mathrm{Na}_{2} \mathrm{SO}_{4}$ ), filtered, and concentrated on a rotary evaporator. The residue was purified by preparative HPLC on a C18 column, using water and MeCN eluent systems. Appropriate fractions were collected, frozen and lyophilized to afford the products as pure compounds.

Analytical Data for Compound 2

IR (neat): 3063 (w), 2981 (m) 2937 (m), 1736 (s), 1613 (w), 1467 (s), 1392 (m), 1367 (s), 1344 (m), 1308 (s), 1266 (s), 1240 (s), $1210(\mathrm{~s}), 1175(\mathrm{~s}), 1150(\mathrm{~s}), 1108(\mathrm{~m}), 1095(\mathrm{~m}), 1031$ (s), $946(\mathrm{~m}), 853(\mathrm{w}), 739(\mathrm{~s}) \mathrm{cm}^{-1}$. ${ }^{1} \mathrm{H}$ NMR $\left(400 \mathrm{MHz}, \mathrm{CDCl}_{3}\right): \delta=$ $7.55(\mathrm{~d}, J=7.8 \mathrm{~Hz}, 1 \mathrm{H}), 7.34-7.28(\mathrm{~m}, 2 \mathrm{H}), 7.22-7.18(\mathrm{~m}, 1 \mathrm{H})$, $5.35(\mathrm{~s}, 1 \mathrm{H}), 4.33-4.21(\mathrm{~m}, 4 \mathrm{H}), 3.81(\mathrm{~s}, 3 \mathrm{H}), 1.30(\mathrm{t}, J=6.9 \mathrm{~Hz}$, $6 \mathrm{H}) .{ }^{13} \mathrm{C}$ NMR $\left(100 \mathrm{MHz}, \mathrm{CDCl}_{3}\right): \delta=166.7$ (2 CO), 137.3, 128.5, 126.3, 123.3, 120.5, 119.5, 109.7, 93.6, $62.4\left(2 \mathrm{CH}_{2}\right), 50.3,32.0$, $14.1\left(2 \mathrm{CH}_{3}\right)$. HRMS: $m / z$ calcd for $\mathrm{C}_{16} \mathrm{H}_{19} \mathrm{O}_{4} \mathrm{NBr}^{+}[\mathrm{M}+\mathrm{H}]^{+}$: 368.0492; found: 368.0491 .

(16) Demissie, T. B.; Hansen, J. H. J. Org. Chem. 2016, 81, 7110.

(17) Demissie, T. B.; Ruud, K.; Hansen, J. H. Organometallics 2015, 34, 4218.

(18) Li, G.; Ward, W. M.; Meyer, G. J. J. Am. Chem. Soc. 2015, 137, 8321.

(19) Pathak, R.; Nhlapo, J. M.; Govender, S.; Michael, J. P.; van Otterlo, W. A. L.; de Koning, C. B. Tetrahedron 2006, 62, 2820.

(20) Hering, T.; Meyer, A. U.; König, B. J. Org. Chem. 2016, 81, 6927. 